\title{
A Cultural Sociology of Populism
}

\section{Marcus Morgan ${ }^{1}$}

Published online: 5 June 2020

(C) The Author(s) 2020

\begin{abstract}
This article interrogates dominant definitions of "populism" found in the social sciences, focusing on the term's conceptual utility in understanding recent changes in Western polities. Though populism is typically treated as a deviant form of politics, this article finds that it in fact holds remarkable continuities with conventional politics, and indeed culture more generally. It argues that these more general cultural processes can be illuminated by cultural sociology, just as the more specific but still routine political processes can be illuminated by Civil Sphere Theory (CST). The article goes on to argue that when populism is understood as a formal mode of public signification, rather than a substantive ideology, the substance it signifies becomes crucial to determining its civility. It suggests that while populism can certainly have anti-civil effects, there is nothing inherent in it that precludes it from also acting to promote civil repair.
\end{abstract}

Keywords Populism $\cdot$ Cultural sociology $\cdot$ Civil Sphere Theory $\cdot$ Political sociology $\cdot$ Left populism $\cdot$ Post-democracy

\section{Populism: Politics as Usual}

One way of characterizing "culture" is as an ever-evolving repository of efforts towards meaning-making. Meaning-making reduces complexity so that communication - and if successful, understanding - can take place. Politics likewise aims towards reducing complexity so as to legitimate efforts to shift, or maintain, power relations. This article will suggest that what has been called "populism" may exaggerate these processes but does not break from them. The purpose is not to reduce

Marcus Morgan

marcus.morgan@bristol.ac.uk

1 University of Bristol, Bristol, UK 
politics to culture, but to show how culture is necessarily "embedded" (to borrow a term from science and technology studies) in culture, and how political action is obliged to conducted itself through culture. Civil Sphere Theory teaches us how this reduction of complexity typically takes place through organizing meaning around a binary structure of motives, relationships, and institutions (Alexander 2006: pp. 5367). ${ }^{1}$ This article will argue that populism is unique only in its accentuation of these binaries, its drawing of an explicit frontier between a construction of the "people"-in progressive populism one that is inclusively defined, in regressive populism, exclusively so (Judis 2016) — and an "elite" (Laclau 2005; Mouffe 2018; Mouffe and Errejón 2016), its development of polarization, its provocation to an audience to decide on which side of the boundary it chooses to stand, and its invitation towards this audience to actively participate in the unfolding political drama, typically through direct, rather than representative, democratic mechanisms.

While the article agrees that useful definitions exclude as much as possible to increase their conceptual grasp, it argues that the difficulty of coming up with a tight, restrictive definition of "populism" is that it is not as tight, restrictive, or discrete a phenomenon as most academic or journalistic accounts present it as being. Rather, populism is best understood as an intensification of routine political dynamics, which are themselves conducted through more generalized cultural mechanisms that allow social signification to take place, group identities to be forged in relation to those they oppose, and collective agency to be mobilized in the process. Populism can therefore be understood within CST, which can itself be understood as following the structures and dynamics of meaning-making illuminated by cultural sociology. From this perspective, different examples of political behaviour come to be seen as more or less populist by degree, rather than populist or not by categorization.

The paper reviews five key features shared across dominant definitions: populism's binary logic, its ideological nature, its moralism, its anti-rationalism, and its anti-pluralism. It both critiques each feature's definitional centrality and stresses each feature's continuities with "conventional" politics, demonstrating how populism functions in ways that CST, and cultural sociology, would expect it to. The paper concludes that populism is compatible with both progressive and regressive political programs, and indeed suggests that if certain criteria are met, there is nothing precluding it from playing a similar role to the social movements described in part III of The Civil Sphere (Alexander

\footnotetext{
${ }^{1}$ Civil Sphere Theory — most comprehensively outlined in Alexander (2006)-provides a novel account of civil society that defines itself in distinction on the one hand, to earlier classical liberal understandings found in thinkers such as Locke and Tocqueville, and on the other hand, to more radical conceptions, associated with the zone in which Gramsci's "war of position" unfolds. It is neo-Durkheimian in its elaboration of the sacred-profane distinction found in The Elementary Forms, seeing similar coding processes as constituting much of the activity that occurs in civil society, the goal of which is understood to ultimately be the moral regulation of society. Since the civil sphere provides the moral regulation of society, this new conception of civil society therefore simultaneously allows for the "autonomy of culture" by showing how culture acts upon other non-cultural spheres of social life. Whilst civil sphere theory focusses on the appeal to ideal notions of solidarity and justice, it acknowledges that such appeals can in reality turn out to be highly contradictory, resulting in the barring of certain groups from civil solidarity through coding them in anti-civil terms that justify their exclusion. Nevertheless, there is an emphasis that appeal to these same cultural codes - which taken as a whole, form the "discourse of civil society" (Alexander and Smith 1993) — can and are used as routes back into civil inclusion. Civil Sphere Theory has been adopted in this article on the basis that its focus on binary coding illuminates many of the operations of populist politics, providing a way of showing how populism, far from being an aberration of democratic processes, is in many ways a predictable feature of them.
} 
2006) in translating restricted political grievances into more universal civil issues, in the process initiating civil repair. Overall, the paper argues against the independence not only of populism but also of politics more generally, from culture. It suggests that beyond violence and coercion, though frequently even within these, power, and the struggles that take place over it, must be seen as operating always and everywhere through culture.

\section{Populism as a Binary}

Attempts to define populism have a long, fraught, and inconclusive history (e.g. Berlin et al. 1968; Ionescu and Gellner 1969). So much so, many sociologists have deemed it wisest to set the ill-defined term aside (Jansen 2011). Events over the past few years have, however, predictably propelled the concept back into academic and public prominence. Though the phenomenon is arguably ancient, the term itself was first used to describe two political movements that appeared at the end of the nineteenth century: in Tsarist Russia, a largely unsuccessful effort at mobilizing peasants against feudal exploitation, and in the USA, the movement of mainly farmworkers who rose up to challenge, via the People's Party, what they conceived of as an elite of bankers, railway owners, and the two-party system of government. In a similar sequence of events to that witnessed with the term more recently, it was first used as a pejorative in the US context, but then quickly re-appropriated by those it was intended to deride. Although some prominent observers argue that the movement around the American People's Party fails the test of a genuine populism (Müller 2016: p. 88), there is fairly broad consensus that one feature it illustrates - a politics built around a dualistic opposition between an "elite" and some conception of a "people", with whom legitimate democratic power belongs - is the basis on which a minimal definition might be agreed upon (e.g. Kreisi 2014; Bonikowski and Gidron 2016; Mudde and Kaltwasser 2017; Eatwell and Goodwin 2018).

However, while the basic notion that "the binary structure of populist claims is largely invariant" (Bonikowski and Gidron 2016: p. 7) may apply to left-wing populisms, it is not so clear that it holds for right-wing variants. Judis describes how while left-wing populism conforms to dominant definitions in its "dyadic" structure, consisting of "a vertical politics of the bottom and middle arrayed against the top", right-wing populism, by contrast, is "triadic", in that such "populists champion the people against an elite that they accuse of coddling a third group" (Judis 2016: p. 15). ${ }^{2}$ This third group is typically a minority, often an immigrant group or some other relatively powerless scapegoat, revealing an exclusivist - i.e. non-universalizing and therefore non-civil-deployment of the "people" in such types of populism.

Definitions based upon the binary criterion also assume there is such a thing as a large-scale politics attempting to win the electoral consent of a polity that does not rely upon some construction of the "people". This assumption is questionable. Democracy is, after all, supposed to be a system in which a people rule (demos-kratos), and even in

\footnotetext{
${ }^{2}$ Making the same point in a slightly different way, Brubaker (2017: p. 362) describes this in terms of a "vertical opposition between 'the people' and 'the elite", as distinct from a "horizontal opposition between 'the people' and outside groups and forces".
} 
non-democratic or "formally democratic" systems, lip service is usually paid to this idea to ensure legitimation (Habermas 1976: pp. 36-37). To operate effectively, such a system must therefore presumably decide who this "people" are. Laclau $(2005,2006)$ has famously argued that constructing a people constitutes the essence of what politics is. Others have suggested that state-formation itself was only possible through determining a "people" (Skinner 2009: p. 328; Peel 2018). In republics, "the people" is typically so central to grounding democracy that it becomes the cornerstone of constitutions, as in "we, the people". In exclusionary right-wing manifestations, "naming the people" is also used, but in this instance, as a means of excluding the "third group" that Judis identifies, justifying the conviction that this group, which is not part of the essentialized "people", is therefore undeserving of political representation. In technocracies, the "people" are also implicitly constructed, but in this iteration, often as in need of the enlightened guidance of experts, on the assumption that the people are unqualified to govern themselves.

Liberal politics is hardly immune, although it typically conceives itself as being so. This can be illustrated by the recent calls for a "People's Vote" on Brexit in the UK. The use of the term "people" here, as in the slogan of the largest march-"Put it to the People" - and in the frequent reference to the number of people on street demonstrations, is unmistakably populist. However, it is arguably a populism against populism; a populism that emerged when a mechanism of direct democracy - a people's referendum on leaving the EU-failed to go the way that liberal anti-populists, who generally defend a more representative notion of democracy, had proposed, a matter that was in part blamed on the populist mould in which organized Euroscepticism took shape. More direct democracy was the liberal answer to direct democracy gone awry; we need to listen more to the people - another referendum is required to establish what the people really think. ${ }^{3}$

Whether or not there is a paradoxical tension between democracy and populism, as some theorists claim (Urbinati 2017), there is perhaps a simple cultural reason why it is so hard to imagine a politics that does not construct a people. This is that political life, like cultural life more generally, tends to organize itself around symbolic boundaries (Lamont and Molnàr 2002) that function on the basis of either/or distinctions, which, when it comes to issues of large-scale group identity, translate into distinguishing between an "us" and a "them". In democratic systems (or as mentioned above, often in non-democratic ones too) since the "people" is the chief democratic category, who is, and who is not, part of the people becomes paramount. Awareness of the social organization of the cosmos around binaries, the corresponding poles of which can be aligned with one another through analogy, synonym, metaphor, and allusion, has been a mainstay of cultural analysis in the social sciences (de Saussure 1893[1915]; Levi-Strauss 1967: pp. 29-54; Barthes 1977; Durkheim 1995: pp. 3339), and one that has been productively developed in The Civil Sphere (Alexander 2006: pp.

\footnotetext{
${ }^{3}$ In this example, we witness a divide between liberal politics in theory and liberal politics in practice. In theory, rather than deriving its legitimacy from a 'people', as populism is said to do, liberalism claims to root its legitimacy in a "population" whose preferences are expressed through voting or polling, and in neoliberal accounts, also through consumption, understood as a proxy for demand. Foucault (2007) adds a critical note to this story, by associating the biopolitical management of "populations" with the emergence of liberal governmentality. In practice, liberalism not only defends itself through its occasional suspension, as Schmitt pointed out, but when politically necessary, also engages in non-liberal appeals to a morally defined "people", in contrast to a "population", as this example illustrates.
} 
53-67). ${ }^{4}$ One need not advocate a Schmittian (2007[1932]) account of radical friend-enemy divisions to acknowledge that the discourse of civil society (Alexander and Smith 1993) cleaves the world into who or what "is" and who or what "is not". 5 These binaries are of course a simplification of the way things really are but this does not make them any less present within, or functional for, political or other group identity processes.

\section{Populism as an Ideology}

There has long been a social scientific perspective that considers populism to be an ideology (e.g. MacRae 1969), providing an overarching normative worldview. Recent mainstream definitions, however, have watered down this position by tending to agree with Mudde's (2004) view of it being only a "thin-centred" ideology, which contrasts to "thick-centred" ideologies (such as liberalism, socialism, or fascism) in that it has "a restricted morphology, which necessarily appears attached to-and sometimes even assimilated into-other ideologies" (Mudde and Kaltwasser 2017: p. 6; see also Albertazzi and McDonnel 2007; Stanley 2008; Ruzza and Fella 2009).

This conception can serve a functional role for those who see themselves as occupying an anti-populist centre-ground in allowing them to critique both an insurgent left and an insurgent right simultaneously, encouraging a horseshoe theory of politics in which the further one travels in either direction on the political spectrum, the more the two extremes begin to resemble one another. As well as damning the left by association, an effect of this has been allowing movements on the far-right to cloak themselves in a more respectable vocabulary than might otherwise have been attached to them, since despite "its ambiguous connotations, the word populism has always been more acceptable than labels like racist or extreme right" (Jäger 2018). However, not only does this lend such tendencies a legitimacy they typically do not deserve but also in defining it as an ideology, populism is asked to carry a weight it cannot bear, resulting in formulations - analyzing the substance of Fidesz's politics alongside Syriza's; Trump's alongside Corbyn's (e.g. Wolf 2017) — that obscure far more than they illuminate. Surely the most salient ideological feature of a politician like Marine le Pen is her nativism and authoritarianism, not her populism, just as the most significant attribute of a

\footnotetext{
${ }^{4}$ Not all traditions of cultural analysis of course subscribe to this notion that our cultural metalanguages are organized around binaries, although many implicitly do. Post-structuralist accounts claimed to reveal the "instability" of binary oppositions, especially as they had been marshalled in philosophy (e.g. Derrida 1981: pp. 41-42), other critiques focus on the eurocentrism of the notion (e.g. Herdin 2012), whilst others prefer to map multidimensional "fields" of cultural distinction (e.g. Bourdieu 1984). Whilst here is not the place to elaborate an adequate defence of the use of binaries in cultural analysis, it is worth noting a few observations beyond the cheap point that many such critiques — Derrida's included — are themselves delivered and made sense of through media that rely upon tacit opposition to generate their meanings. First, positing the binary structure of cultural forms is not of course the same as making an ontological claim about the world itself being thus organized, or even, for that matter, our cognitions or feelings. It is instead making a claim about the publicly available shared symbols through which sense is made. Second, arguments for binary understandings of culture originally arrived in the social sciences through anthropological fieldwork in non-Western societies, albeit typically conducted by Western anthropologists. Third, "fields", as they are conventionally mapped through techniques such as multiple correspondence analysis, rely upon the assumption of binary poles, even if complexity is introduced through binding one opposition orthogonally to another. Such practices do not sit uneasily alongside the proposition of the binary organization of meaning; they simply track the multiplicity and empirical intertwinement of those oppositions.

${ }^{5}$ This explains why civil incorporation, for instance, is not a process that comes about spontaneously, but is hard won through symbolically oriented political struggle (Alexander 2006: pp. 425-457).
} 
politician like Sanders is his democratic socialism. If populism is just a byword for being against the status quo, then it functions to permit groups to frame themselves as defenders of anti-populism rather than defenders of the status quo. Conceiving populism as an ideology forfeits its analytic utility by failing to mark out anything useful.

These kind of difficulties have led some to jettison the notion of populism as ideology - be it thin- or thick-centred - entirely, and argue that it is not an "actor-level" phenomenon, but a "speech-level" one, revealing how "politicians often rely on populist language selectively, presenting the same political claims in either populist or non-populist terms depending on the audience and broader social context" (Bonikowski 2016: p. 13). Whether this involves arguing that populism is more akin to a "discourse" (Aslanidis 2016), a "rhetorical strategy" (Bonikowski 2016), a "style" (Ekström et al. 2018), a "stylistic repertoire" (Brubaker 2017), or a "frame" (Aslanidis 2018), this alternative perspective recognizes that populism refers more to the form through which politics is done, than to any specific ideological content. Seeing populism in this way ties it to appearance; impression; aesthetics; and, importantly, performance (Moffitt 2016). Adopting this alternative understanding is therefore attractive to a cultural sociological approach, for it allows populism to be set free from debates over substantial content, and yoked instead to the symbolic struggles of civil spheres, and the meta-discourse of civil society through which they occur.

When we understand populism in this performance-based way, we again detect it in places where those who use the term as simply a shorthand for politics they disagree with might not expect to find it. Tony Blair, for instance, whose Institute claims to work to "push back" against the "threat from a rising tide of populism" 6 relied extensively on populist signification while leader of the Labour Party, to the extent that one initially enthusiastic (though quickly critical) cultural theorist, Stuart Hall, came to recognize him as epitomizing populism (1998: p. 13). The following flourishes from Blair's 1999 Conference Speech might be given as typical examples:

The future is people. ... The national creative genius of the British people. But wasted. The country run for far too long on the talents of the few, when the genius of the many lies uncared for, and ignored .... The old elites, establishments that have run our professions and our country too long .... the elite have held us back for too long ... New Labour, confident at having modernised itself, now the new progressive force in British politics ... can modernise the nation, sweep away those forces of conservatism to set the people free. (Blair 1999)

The eminently populist slogan "For the Many, Not the Few," now associated with Corbyn's "populist rebranding" of the Labour Party (Stewart and Elgot 2016) also found its initial airing during Blair's controversial redrafting of Clause IV (the clause in the Labour Party Constitution that prior to Blair's amendments referred explicitly to the socialistic aim of securing "common ownership of the means of production"). ${ }^{7}$

Obama likewise deployed populist language in his various campaigns, and on occasion explicitly identified himself with the term (Obama 2016). The "We" in the slogan "Yes We

\footnotetext{
${ }^{6}$ See Tony Blair Institute for Social Change, "Our Mission: Renewing the Centre", at https://institute.global/ renewing-centre.

${ }^{7}$ Corbyn has explicitly connected the theme in various public rallies to the final line of Shelley's famous poem on passive resistance during the Peterloo Massacre, The Masque of Anarchy: "Rise like Lions after slumber, In unvanquishable number-Shake your chains to earth like dew, Which in sleep had fallen on you-Ye are many-they are few."
} 
Can", for instance, evoked a constructively ambiguous "people". Originally, a slogan of Cesar Chavez's United Farm Workers ("Sí, se puede"), the phrase was most famously used by Obama in the rousing 2008 speech he delivered in Chicago's Grant Park upon winning the presidency. After telling the assembled crowd that this is "your victory", he concluded his rhetorical tour de force by making the connection explicit: "[W]here we are met with cynicism and doubts and those who tell us that we can't, we will respond with that timeless creed that sums up the spirit of a people: Yes, we can". Eight years later, the phrase provided the name for the archetypal left populist party that grew out of the indignados movement in Spain, Podemos.

Mudde and Kaltwasser at moments recognize such continuities between the public performances of populist and (apparently) non-populist leaders, but since their understanding of populism is rooted in a substantial conception of ideology, they dismiss them as simply attempts by non-populists "to set themselves apart from other mainstream politicians and (try to) look authentic" (2017: p. 76). From a cultural sociological perspective, in which politics in mass societies is performance (Alexander 2010, 2011; Mast 2012), this distinction makes little sense. Viewing populism as a mode of public signification rather than a thin-centred ideology not only reveals its continuity with other forms of politics but also allows us to see populism as a form of cultural work, a way of narrating "brute facts" and making them meaningful. Its efficacy (or lack thereof) can then be explained through its success in mobilizing the binaries of the civil sphere, attempting to align its own motivations, relationships, and institutions to the positive poles of civil codes and polluting those of its adversaries.

\section{Populism as Moral}

A third common theme in recent influential definitions has been to emphasize morality as existing at the core of populism. Mudde and Kaltwasser claim that "the key distinction in populism is moral" (2017: p. 35), Bonikowski (2016) argues that "populism is based on a rudimentary moral logic", and Müller suggests that the term should only be used to identify "a particular moralistic imagination of politics" in which the "people" are conceived as morally untainted, whereas the "elites" are understood as morally corrupt (2016: p. 20). In this manner, populism's tendency to divide the world into "good" and "evil" is deemed to be both reductive, in that it eschews nuance in favour of Manichaeism, and dangerous, in that it excites collective anxieties and resentments rather than providing discursive space for dispassionate assessments of competing courses of action, meaning that "the likelihood of productive dialogue and compromise is reduced" (Bonikowski 2016: p. 22).

From a cultural sociological perspective, however, using morality as populism's differentia specifica is again unsatisfactory. This is because not only are moral ideas themselves seen to be always and everywhere culturally formed (Durkheim 1973; Geertz 1968; Douglas 1983; Morgan 2014) but also are morals recognized as animating almost all other instances of social classification (Durkheim and Mauss 2009[1903]: pp. 48-52). Processes of moral idealization are, as Stavrakakis and Jäger (2018: p. 13) point out, "present in nearly all identifications, in all passionate attachments, from love to religion and from cultural taste (distinction) to football"; therefore, they ask, "How could power relations be exempt? Especially since identity and difference, love and hate, play such a significant role in all political identification?" While this point is occasionally acknowledged (e.g. Müller 2016: p. 38), its consequences fail to be. 
Political philosophy, including most of the classical cannon-Plato, Aristotle, Kant, Mill, etc. - has long been characterized by an extension of moral philosophy into the public sphere, since both ultimately deal with normative matters of "what should be" rather than "what is". There is no need to agree with Crick's interest-based account of politics (Alexander 2006: p. 111 ) to accept his contention that "conflicts, when personal, create the activity we call 'ethics' ... and such conflicts, when public, create political activity" (Crick 1962: p. 20).

This continuity between individual, social, and political life, of which populism is a part, can be made sense of through the resources offered by a social science that places symbolism at its centre. Once contemporary societies are recognized as alive with the sacred (Durkheim 1995[1912]: pp. 418-448; Lynch 2012), processes of public symbolization can no longer be presented as supplying flat cognitive maps of the world - a mere semiotic metaphysics - but must instead be seen as "suffused with an aura of deep moral seriousness" (Geertz 1957: p. 421). Populism's attempt to associate the sacred with a construction of "the people", in which democratic legitimacy rests, and the profane with a construction of "the elite", of course reduces the complexity of the actual world, but the "nuance and ambiguity of empirical actions does not often make an appearance in the public language of civil society" (Alexander 2010: pp. 10-11). Civil society's dichotomies not only organize meaning made elsewhere but also through their relative autonomy as culture structures in fact partially generate this meaning (Alexander and Smith 1993). The struggles that take place around identifying good and evil and the arraying of events, issues, and figures on either side of this binary, constitutes much of what goes on in the civil sphere, and just as populism is said to connect an idealization of the "people" to a vilification of the "elite", so The Civil Sphere (Alexander 2006: pp. 193-209) shows how the discourse of liberty and the production of civic virtue is internally connected to the discourse of repression and the production of civic vice. Since this is an empirical and not a normative claim, it is also resistant to the charge that it falls victim to the fallacy of the excluded middle: the question of whether or not binary moral distinctions are nuanced or correct is irrelevant to the recognition that they hold social force.

Indeed, it is clear that the symbolic work involved in the very attribution of "populism" to certain forms of politics, and not to others, is typically itself accompanied by a heavy dose of moralism (Taguieff 1995), to the extent that we may wish to ask "whether or not having become an accusation, it can remain an analytic concept" (Geertz 1973: p. 194). There is more than a little truth in Francis Fukuyama's (2016) claim that "populism is the label that political elites attach to policies supported by ordinary citizens that they don't like". Others have gone further, arguing that liberal anti-populism in fact hinges upon a substitution of broader political discourse for a narrower moral one. Mouffe (2002: p. 1), for instance, in an extension of Schmitt's argument that liberalism rests upon an impossible attempt to evacuate the category of the "political", has argued that such approaches mean that ethical deliberation is asked to fill the role of political struggle: "we are now urged to think not in terms of right and left, but of right and wrong".

There are also good reasons morality in political affairs ought to be welcomed. First, the notion that collective moral resentments are automatically unacceptable in political life and that reaching a compromise that is pre-written into institutions that already exist is desirable, rules out many of the most valuable political advances - including those discussed at length at the end of The Civil Sphere Alexander (2006) — as beyond the pale. It threatens to imply the notion that "politics as usual" should form the horizon of politics in general. In apartheid South Africa, rational dialogue with an unjust system was impotent at tackling the predicament that Blacks faced. Legitimation of collective moral grievances with domestic and international audiences, 
the association of the state with evil, and the association of the freedom struggle with good was far more crucial to winning civil incorporation than processes of public deliberation (Morgan 2018, 2020).

Second, politics without a moral element risks transmuting into managerialism, and it is in fact the insistence upon this failed conception of what politics involves - what Michael Sandel (2018) calls "technocratic liberalism"- that helps in part explain the collapse of so many liberal democratic parties in recent years at the expense of populism. Sandel argues that after years of a predominantly neoliberal form of globalization - in which moral and cultural injustices, tied to economic inequalities, have been typically experienced by political subjects as a denial of social esteem - it is important that a clear and progressive moral voice returns to political life. Indeed, he sees such a return as doubly necessary, in that strident moral voices already exist in right-authoritarian populist movements, the seductions of which can only be countered by an equally robust justification of the moral imperative of progressive politics. Denying this imperative in the name of a fictitious liberal neutrality not only, by default, cedes moral questions to the sphere of private deliberation but also feeds the very forces it claims to oppose.

Once again, a feature purported to be unique to populism turns out to in fact be a characteristic of politics more broadly conceived, revealing more universal features of the civil sphere, and in fact cultural life more generally. Not only is morality inadequate as a distinguishing feature of populism but its conscious re-introduction back into politics might also be treated as a welcome development.

\section{Populism as Irrational}

Classical social theory was preoccupied with the shift from traditional to modern societies, accompanied by a corresponding shift from myth to reason as the predominant organizational principle of social life. Whether through a movement away from the "theological" through the "metaphysical" towards the "positive" stage, or through processes of "disenchantment" or "bureaucratization", or even "the rational development of productive forces", the classical progressivist assumption was that modernity was defined by a process that - albeit typically with internal contradictions - unleashed and expressed rationality. Although Durkheim (1984[1912]) was not himself immune to this assumption, as can be seen especially in his early doctoral dissertation on the shifts in the division of labour in society, he nevertheless came to recognize, and especially so in his late work, that "there is something eternal in religion", and that "common sentiments" conveyed through symbols, and sustained through rituals, infused modern life far more profoundly than the modernization stories had allowed for (Durkheim 1995[1912]: p. 429).

As the previous section argued, categorical symbolization is rarely a neutral process, and the terms "rational" and "irrational" typically carry moral evaluations. Establishing the irrationality of those with whom one disagrees has proven a time-honoured means of pollution. From Arnold's (1993[1869]: p. 79) description of the "anarchy" of the "raw and unkindled masses" or Le Bon's (2006[1896]: p. 10) account of the crowd as characterized by "impulsiveness, irritability, incapacity to reason, absence of judgement and critical spirit, and exaggeration of the sentiments", which he noted were "almost always observed in beings belonging to inferior forms of evolution - in women, savages, and children", the charge of irrationality has long functioned as a powerful means of exclusion (Foucault 1988). 
Perhaps unsurprisingly, therefore, populism is often described as an irrational tempest in the calm waters of rational politics (Goodhart 2017: p. 57). In the UK, the Brexit vote was widely treated as an accidental outburst of xenophobic irrationalism, just as Corbyn's initial support was initially explained away as "summer madness" (Toynbee 2015), and later diagnosed as “Corbynmania”. As Müller (2016: p. 1) notes, typically "populists are 'angry'; their voters are 'frustrated' or suffer from 'resentment'”. While Müller (2016: p. 101) himself avoids such associations, other influential accounts oppose the populist idea of a "general will" to the more "rational process" of political deliberation "constructed via the public sphere" (Mudde and Kaltwasser 2017: p. 18), characterize populists as specializing "in action" but "rarely attempting deep thought" (Canovan 1999: p. 15), or else locate the dangers of populism in its tendency "to encourage politics based on fear and resentment rather than informed policy debate" (Bonikowski 2016: p. 22; Rico et al. 2017). Even cultural sociological accounts have located populist motivation in the "allure" of the "irrational" (Wagner-Pacifici and Tavory 2017: p. 319), though others have correctly recognized that we need not agree with the reasons behind populism to acknowledge that such reasons exist (Gorski 2017: p. 348).

Relying as it does upon the civil structure that sacralizes reason and profanes its opposites (Alexander 2006: p. 57), othering populists as irrational helps simultaneously reassure antipopulists of their own reasonability. It also helps avoid uncomfortable questions concerning the links between anti-populist politics and the recent rise of passionate populism they so fear. The discourse of "populism", when used in this undeniably moral way, likely entails the unintended consequence of encouraging the very phenomenon it condemns, since populist sentiments rely upon an image of a distant elite, always ready to counter reports of lived experience with carefully reasoned arguments. We therefore see a "working of the binaries" (Alexander 2010: pp. 89-110) in the very identification of populism as irrational: because "liberal-democratic capitalism has imposed itself as the only rational solution to the problem of organising modern societies; its legitimacy could be put into question only by an 'unreasonable' element" (Mouffe 1999: p. 3).

The apparently less-excitable politics to which populism is typically contrasted features in political theory in the contention that fundamental questions and antagonisms can be rationally answered and overcome by public reasoning. This approach is associated most famously with Kant, and later developed in different ways by Rawls and Habermas. It is also an approach that is critiqued in The Civil Sphere (Alexander 2006: pp. 13-17). Turner (2015) defends against this critique, contrasting a broken American political sphere in which "politics as performance have so far blocked the emergence of a rational policy of economic and financial reform", with a more rationalistic British one, in which the emotivism of Thatcher is presented as an aberration - "the only example of a recent British prime minister who walked the boundaries and talked the binaries" (Turner 2015: p. 69). Churchill, who we are told was "undoubtedly the twentieth-century hero of British political life" was apparently "not inclined to conduct domestic political elections on the basis of a moral binary" (Turner 2015: p. 70). Turner neglects to mention Churchill's record in domestic elections, never having won the national popular vote, and having been voted out of office as soon as the deeply polarized and emotionally charged atmosphere of World War II - which Turner (2015: 70) concedes ought to be seen "as a titanic struggle between the noble virtues of liberalism and the craven values of fascism" - concluded. Since not long after Turner's piece was published, and certainly since the EU referendum, it has become almost a cliché to suggest that British parliamentary and extra-parliamentary politics have become increasingly emotional. Commentaries on the rise of populism in the UK typically point out the deepening and sharpening of the binaries of 
political life, the failure of "phlegmatic" and "lugubrious" characters, and the rise of charisma and emotion as core to political success. As Davies 2019: p. 15) puts it in a recent book on the phenomenon: "Democracies are being transformed by the power of feeling in ways that cannot be ignored or reversed". Increasingly, social scientific studies have identified the impossibility of an emotionless politics, whatever one's substantive political orientation (Loseke 1993; Marcus 2000; Weber 2012).

By drawing on Durkheim's insights, one thing that CST offers in making sense of the debate over whether populism ought to be characterized as rational or emotional, is a way to transcend the opposition itself. It does this through a focus on symbolics, ritual, and performance. Sign systems are rationally ordered in structured ways that depend upon distinction, difference, and opposition to generate meaning. What society decides to make sacred, for instance, it does so by ensuring that it is "set apart" from the profane (Durkheim 1995[1912]: p. 44). In generating such meaning, these categories move beyond being merely analytic codes and begin to acquire moral and emotionally laden social significance. While others have convincingly demonstrated how emotion and reason are almost always mutually embedded within the "alchemies of the mind" (Firth 1958: pp. 150-183; Elster 1998; Goodwin et al. 2001), focusing upon symbolism, and the ritual processes that take place around it, has the added advantage of again revealing the continuities between apparently highly variable cultural practices. In this case, it allows us to see populism as consistent with other forms of politics, and indeed public culture more generally, since all are compelled to operate through the same symbolic channels.

The Civil Sphere (Alexander 2006) stands in opposition to two influential political models: interest-based and deliberative democratic. In place of these models, it offers an approach in which successful performance is capable of redrawing the boundaries of solidarity and moral cohesion. Performance trumps realism and ontology, since it is the performed appearance of sound judgement, fairness, integrity, or truth that matters, not the ontological presence or absence of such things. ${ }^{8}$ Politics, like culture more generally, works through persuasion, not rational accomplishment, enlightened revelation, or the realist resolution of some conjunctural balance of forces. ${ }^{9}$ While symbolization (the medium of performance) takes place within a rationally ordered (and therefore rationally accessible) set of binaries, these binaries do not remain mere cold logical distinctions. Moreover, the claims that are made for where particular events, relationships, or figures are to fit within this logical structure succeed or fail on the basis of their appeal to an audience's feelings. This means that the same rules of performative success apply whether one's cause is in fact worthy or not. Since political struggle is, at its heart "moral and emotional" (Alexander 2010: p. xii), this paper will later argue that suppressing these elements in an effort to achieve some pristine reasonability simply yields these potent motivational resources to whatever other political forces are prepared to use them.

\footnotetext{
${ }^{8}$ This account of politics resonates with humanistic accounts of knowledge, in which "truth" is a compliment we ascribe to knowledge that seems to be "paying its way" or managing to convince a relevant community on the basis of that community's standards of justification (James 1981[1907]; Rorty 1982: p. xxv; Morgan 2016).

${ }^{9}$ This point has been forcefully made in an astute study of social movement success by Woodly (2015), in which she argues that political victory depends upon "political acceptance", which is distinct from "political agreement". Whereas the latter involves acceptance of a movement's policy goals, the former is simply an acceptance of the cultural relevance of a movement's concerns to public discourse.
} 


\section{Populism as Anti-Pluralist}

A final definitional criterion that dominant accounts of populism tend to reach consensus around is the notion that populism is a way of conducting politics that is by its nature "antipluralist" (Galston 2018). Although it speaks "the language of democracy", populism, so we are told, is in fact "always anti-pluralist" and therefore offers a "degraded form of democracy" (Müller 2016: pp. 3, 6; see also Mounk 2018). ${ }^{10}$ This is apparently linked to its Rousseauian claim to represent the "will of the people", but doing so in a non-institutionalized manner that treats the categories of the "elite" and the "people" as "homogeneous wholes" (Müller 2016: p. 6; see also pp. 7, 12, 18). This non-empirical "claim to exclusive representation" (Müller 2016: p. 6) is said to lead to a second danger with populism: an inability to recognize the legitimacy of its opponents (Bonikowski 2016: p. 22). This section will address these connected claims in turn, arguing that while they may provide an accurate account of certain varieties of populism, they by no means apply to all instances and, therefore, once again, fall short as definitional criteria.

Populists, we are told, consider "society to be ultimately separated into two homogeneous and antagonistic groups" (Mudde 2004: p. 543; Müller 2016: pp. 6, 18). This is said to derive from their sharing an understanding of "the political" with Schmitt, who believed that "the existence of a homogeneous people is essential for the foundation of a democratic order", and in listening to what Rousseau called the "general will" of this homogenous group, "those who do not belong to the demos ... consequently, are not treated as equals" (Mudde and Kaltwasser 2017: p. 18). Populism is therefore said to be irredeemably anti-pluralist in its rejection of an image of "society as a heterogeneous collection of groups and individuals with often fundamentally different views and wishes" (Mudde 2004: pp. 543-544).

Such charges may apply to nativist populisms, but there are good reasons to assume that it is the nativism, not the populism, that produces them. While inspired by Carl Schmitt (Mouffe 1999), left populist theory departs from his thinking at various significant junctures. One such juncture is that neither the "elite" nor the "people" are considered homogenous wholes. Drawing on Gramsci, theorists of left populism have instead argued for the importance of articulating the fundamentally heterogeneous interests of segmented groups into a "people". Gramsci (1971: p. 191) had argued that successful leaders and parties could articulate disconnected groups, transforming them "from turbulent chaos into an organically prepared political army". If the "people" in left populism were conceived as a pre-existing homogenous unit, as the mainstream definitions suggest, such hegemonic articulation would clearly be unnecessary: articulation is required precisely because heterogeneity is acknowledged. Constructing salient shared distinctions by drawing a political frontier is very different to claiming homogeneity. The very power of the concept of "the people" to mobilize - which, if the arguments above are accepted, it must be acknowledged as a power it holds over liberal democracy as much as the radical democracy advocated by left populism - is its capacity to act as an "empty signifier" to be filled with whatever content political agents determine (Laclau

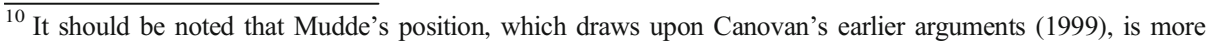
nuanced, arguing that populism is in many ways more democratic (yet less liberal) than liberal democracy, which is characterized as "a complex compromise of popular democracy and liberal elitism, which is therefore only partly democratic" (Mudde 2004: p. 561). Alexander (2010: pp. 278-279) also touches on this point in his discussion of how the democratic resonances of the Preamble to the US Constitution's reference to "We, the people" were tempered by the more liberal specifications of the Bill of Rights amendments.
} 
1996). This is also, of course, what allows it to lend itself to both right- and left-wing invocations (Badiou et al. 2016).

Due to its moralistic nature, populism is also charged with being "typically based on a fundamental rejection of the political legitimacy of one's opponent", so that "the likelihood of productive dialogue and compromise is reduced" (Bonikowski 2016: p. 22). ${ }^{11}$ While this charge no doubt applies to certain forms of what Stuart Hall (1979) called "authoritarian populism", it again sits uneasily with theories of left populism, which have been at pains to stress that while politics will never be able to eradicate antagonism entirely, such conflicts can, and should, be transformed into "agonistic" relationships (Mouffe 2013). Whereas Schmitt (2007[1932]: p. 26) saw politics as in essence defined by an antagonistic, and ultimately lethal, struggle of friends against enemies, Mouffe (2013) both critiques the opposite rational-liberal view that a non-antagonistic consensus lies hidden, awaiting discovery through reasoned debate, but also argues that antagonism can be transformed into agonism through appropriate democratic institutions; the very institutions that mainstream accounts would have it that populists undermine. Whereas the Schmittian image is a war against enemies, the left populist image represents a struggle against adversaries in which the viewpoints of one's opponents are taken seriously as authentic viewpoints. The adversary becomes "a legitimate enemy with whom there exists a common ground", and while adversaries might "fight against each other", they nevertheless - in stark contrast to what populism's critics charge - "share common allegiance to the ethico-political principles of liberal-democracy" (Mouffe 1999: p. 4).

This transformation of enemies into adversaries, antagonism into agonism, opens up the possibility of a civil populist politics, in other words, a populism conducted within a broader shared civil solidarity, which makes reference to the same civil metalanguage as that of its opponents. It is presumably for this reason that Alexander quotes Mouffe's work appreciatively in The Civil Sphere, in its insistence that "'the novelty of democratic politics is not the overcoming of this us/them opposition.' The challenge, rather, 'is to establish this us/them discrimination in a way that is compatible with pluralist democracy.' ... which 'consists in domesticating hostility"' (Alexander 2006: p. 124). What Mouffe describes as the "conflictual consensus that constitutes the basis of a pluralist democracy" (Mouffe 2018: pp. 91-92), Alexander would, I suspect, simply call the routine struggles that occur with reference to the shared "discourse of civil society", in which neither the possibility of consensus nor progress is assumed, but the legitimacy of one's opponent certainly is.

Interestingly, even within varieties of national populism (Eatwell and Goodwin 2018) that endanger but fail to break civil autonomy, these conditions can hold to the extent that "enemies" can be refashioned into "frenemies" (Alexander 2019: p. 6). What is threatening about such forms of populism, typified in figures like Trump, is less their delegitimizing of opposition and more their direct assault upon civil institutions (the judiciary, the media, the scientific establishment, etc.) which can ideally act to ensure the autonomous functioning of the civil sphere (Alexander 2019: p. 8; Kivisto 2017). These conditions clearly do not hold in the more extreme expressions of exclusionary populism that Trump routinely flirts with, and various European leaders have chosen to embrace. Such populist manifestations use an appeal to "the people" as a way of injecting antagonism into areas of the state and civil society which liberal democracies base their legitimacy on defending. If the perimeters of the judiciary, the

\footnotetext{
${ }^{11}$ As argued in the section before last, an irony that is too often lost in such claims is that the moralizing rhetoric of liberal anti-populism can itself come across as anti-pluralist, not only through the ease with which it shades into elitism, but in its rejection of the legitimacy of what it conceives as populist voices by labelling them such.
} 
civil service, the media, the scientific establishment, and so on (which may themselves of course be distorted by other societal spheres) become penetrated by these forms of power, then populism risks decomposing into authoritarianism. Moreover, these expressions of populism bar and expel on the primordial bases of blood or soil and in so doing attack the foundation of the shared togetherness that defines membership in the civil sphere. In such cases, agonistic struggle slips into antagonistic battle, and what Victor Serge called "respect for the man in the enemy" (Serge 2012[1951]: p. 375) is indeed lost. However, this loss is not a function of populism but of authoritarianism, nativist essentialism, and the quest for purity - political tendencies that appear both in the presence and absence of populist signification.

\section{Populism as Civil Repair?}

The focus of dominant definitions of populism has typically been upon its dangers, distortions, and reductions. The one consistent virtue identified in such accounts is its capacity to act as a canary in the coal mine for social grievances (Bonikowski 2016: p. 23; Mudde and Kaltwasser 2017: p. 40). Here, I would like to argue that just as it can function as a threat to civil solidarity, populism also holds the potential to act as an agent of civil repair.

There are at least two ways of telling the story of the recent rise of populism. One is that healthy, responsive, and pluralist liberal democratic systems were unexpectedly rocked by the eruption of irrational forces. This story posits populism as the cause of Western polities' current ills. There is, however, an alternative story, which casts populism as an effect as much as a cause, and which can be told by drawing upon the ideal types of the civil sphere.

This story begins by decentering populism and instead bringing into focus the democracies in which it has arisen. Although the civil sphere is analytically independent, actual civil spheres are "always deeply interpenetrated by the rest of society" (Alexander 2006: p. 194; also 2013: pp. 123-124). Non-civil spheres constantly edge into the civil sphere, threatening to distort its priorities. Such spheres aim towards more restrictive goals, employ variant standards of justice, and exchange information through alternative media. The economic sphere poses a particular threat to civil imperatives in its pursuit of profit above justice and efficiency above solidarity, and its communication through the reductive medium of price rather than the rich symbolics of performance. While Alexander (2006: pp. 206-208) recounts the beneficial inputs of the economic into the civil sphere, he also notes the obvious risks it poses to the solidarities of civil life.

The alternative story of the rise of populism identifies how, from the late 1970s onwards, Western liberal democracies progressively submitted to a narrow set of economic priorities, allowing the market to structure sectors - education, utilities, healthcare, social care, transportation, etc. - in which civil imperatives had previously governed during the post-war consensus period. Many of the Western leaders that rose to power in the wake of this Reagan/ Thatcher revolution not only continued to welcome market forces into the civil domain but also attempted to evacuate not only antagonism but also agonism from politics too. Through political triangulation, the arbitration of competing demands, and the technical administration of the economy, initially highly popular leaders such as Blair, Schröder, and Clinton attempted to forge a consensus politics "beyond left and right" (Giddens 1994) in which "debate on the sensible givens of a situation" (Rancière 2003: p. 4) became stifled. This did not of course mean that fundamental social conflict disappeared-social movements in the global North blossomed during this period-but this conflict struggled to find adequate expression in 
institutionalized democratic channels. While all the traditional institutions of democracy remained intact, an increasing proportion of the imperatives driving decision-making became outsourced to experts (Crouch 2004), and the role of the demos, upon which democracy apparently rested, became more and more circumscribed (Rancière 1998). When democratic processes were required, marketing and public relations mechanisms - such as focus-groups and professional communications strategies - increasingly stepped in to devise or defend "policy" in a manner that fundamentally divorced it from "politics" (Schmidt 2006). Governance began to resemble management, the revolving-doors between political assemblies and elite private sector organizations began to spin ever-faster, apathy increased, party membership and voter turnout dropped (Mair 2013), and democratic societies entered their "post-democratic" phase (Crouch 2000).

At no time was this more apparent than following the 2007-2008 economic crisis. A global event caused by elite economic mismanagement was met with a political response that protected this elite, on their own advice, at the expense of broader populations. The choice to pursue austerity policies was of course felt materially, but their effects were also experienced symbolically, in ways that solidified public distrust in politico-economic elites. Across Europe, but especially so in Southern European countries like Spain and Greece, "necessary" economic imperatives further colonized areas in which civil solidarity had once held sway.

Social democratic parties founded in the nineteenth or the early twentieth centuries in an attempt to provide representation to workers and offer institutional barricades against the anti-civil incursions of the economic sphere detached themselves from their traditional electoral base by failing to shield them against swingeing public service cuts, or even pioneering their implementation. Such parties are now paying the electoral price (Bickerton 2018). While centre-right parties had long been comfortable with market priorities driving public policy, this unholy pact between social democratic organs and the market, combined with the associated evacuation of agonism from politics, provides an alternative account of where the populist "backlash" (Alexander 2019), in both its regressive and progressive manifestations, originated.

All this is not to say that the recent wave of what has been labelled "populism" can be reduced to an epiphenomenal effect of a post-democratic political culture meeting its postcrisis moment. The evident success of populism as a mode of doing politics has led to it becoming an effective and autonomous culture structure in its own right, and one that has been self-consciously drawn upon and implemented by politicians eager to win votes. Moreover, cultural work invariably mediates between the reality and the perception of public issues, and the populisms that have sprung from this neoliberal postpolitical landscape have worked away at making these material and political realities meaningful. It is hardly a great surprise that antielitism has characterized many of them. Some have made austerity meaningful through a focus on ethnically or racially marked "enemies within", who they identify as really to blame for the lack of opportunities and declining public services, and in the process have degraded civil solidarity even further.

Other populisms, however, have kept open the possibility, though by no means the guarantee, of civil repair. This is especially the case where populist signification has been combined with substantive policy to address those grievances — both moral and material — that nativist populism feeds upon. Such populisms promise a return of the political by drawing excluded groups into the democratic orbit in ways that can "translate" their sectoral grievances into universal civil issues of concern to societies at large (Alexander 2006: pp. 231-232). Populism, conceived in the weak, formal manner argued for in this paper, has not been the 
primary cause of the current crisis of Western politics, though certain of its expressions can no doubt be seen to have hastened this crisis. The challenge for progressives is to resist treating it as some easy solution. Nevertheless, drawing upon the preceding discussion, we might identify certain conditions that would enhance its viability, when combined with appropriate substantive policy, to act in the interests of civil repair.

First, in the discussion of the binary feature of populist politics and the critique of the tendency to treat populism as an ideology, it was argued that we need to challenge the notion that contention is alien to democracy and that the solution to populism is a return to a consensus style of public administration. Friend-enemy, us-them, and pure-polluted distinctions, which are often presented as unique to populism, cultural sociology teaches us, are in fact expressions of more universal culture structures, which when evoked in an agonistic manner can be understood as homologous with the binaries that compose the "discourse of civil society". As the three examples that form part III of The Civil Sphere illustrate, it has been precisely the construction of political frontiers around pressing issues that has historically led to civil expansion. ${ }^{12}$ If movements had not convincingly used the discourse of civil society to simplify reality into good and evil, coding those forces pushing for civil repair as pure and those acting against it as polluted, the success of these movements would have been far less certain. However, if populism is understood as a formal mode of political signification, rather than a substantive ideology, the substance with which it works is clearly critical. Polarization needs to occur around the right issues, and issues that social movements have brought to the fore in recent years, and populist politics may be well placed to carry forward, include those around inequality and climate degradation. Compelling arguments exist that such issues deserve to be made subject to the binary treatment of the discourse of civil society, since they have been inadequately addressed by the routine functioning of civil sphere institutions, especially under the distorting influence of market-oriented imperatives.

Since civil repair will emphatically not be brought about by a triadic populism that scapegoats social ills on communities that were neither responsible nor hold the power to defend themselves against such charges, it is also key that such frontiers be open and inclusive. This inclusivity must involve a willingness to hear the grievances of those seduced by exclusivist populism, and a preparedness to invest in the cultural work necessary to reframe their concerns in universalizing, civil terms. Whether it comes from the left or the right, any populism that defines the frontiers of political life in essentialized and closed, and primordial terms is, by its very nature, non-universalizing and anti-civil.

Second, it was suggested that treating morality and emotion as automatic threats to democratic politics is likewise problematic. Not only does this position too often fall back upon the flawed alternative assumption that political contention is settled only through ratiocinative modes of public discourse, drained of values or feelings, but it also cedes these powerful motivating forces to those anti-civil tendencies currently using them to such great effect. Just like civil restriction, the success of civil translation depends upon its appeal to feelings, beliefs, and ideals as much as cognition. Neglecting moral language and emotive performance in the public signification of politics is not only foolhardy in an environment in which anti-civil forces readily make use of it, it can also be experienced as an affront by groups whose exclusion is experienced in moral terms, and whose anger at such exclusion is felt in visceral ways. A populism capable of civil repair would therefore need to be culturally creative

\footnotetext{
${ }^{12}$ It is worth noting how many of the new populist parties and their leaders have emerged from what The Civil Sphere identifies as the primary agents of civil repair: social movements.
} 
and dramatically astute in its telling moral tales, harnessing public feeling and constructing shared affect. This would involve engaging not only in the statics but also in the dynamics of the civil sphere (Alexander 2006: pp. 60-62), fashioning compelling narratives capable of supplanting those of restrictive, anti-civil populism. Feelings mustered in support of civil restriction will not be conquered simply by reasoned arguments, but by evoking more powerful feelings in support of civil expansion. Compelling exclusionary narratives will not be displaced simply by a presentation of facts, but by crafting even more compelling universalizing stories. ${ }^{13}$

Thirdly, populism must be both agonistic and pluralistic if it is to function as a force for civil repair. Working within the shared semantic coding of the civil sphere and elaborating dynamic narratives capable of inspiring hearts as well as minds, such a populism would need to treat its opponents as adversaries to be struggled with and ultimately persuaded, rather than enemies to be silenced and ultimately eradicated. Its pluralism would derive from its creation of a "people" composed of coalitions articulated across difference. Such difference would need to be conceived not as a problem to be overcome, as in völkisch conceptions of a "people", but as a resource to be celebrated or a productive tension capable of promoting civility by occasionally testing it. Such articulations will fail if they are conceived as rooted within the spontaneous alignment of pre-determined "interests". Instead, they must be understood as the outcome of ongoing cultural work aimed at tying together segmented grievances into hegemonic civil solidarities. In this sense, a progressive appeal to the "people" would need to be seen as a forever unfinished project.

\section{Conclusion}

The preceding section has suggested that like the social movements described in the final part of The Civil Sphere (Alexander 2006), populism can promote civil repair by translating restricted sectoral grievances into universal civil concerns, with the goal of incorporating previously excluded groups into the fold of social solidarity. Such processes are neither guaranteed nor often complete, however. Populisms can either fail in their efforts at representation, faltering in their capacity to successfully mobilize the metalanguage of civil society, or they can push — consciously or not - in the opposite direction, asserting particularistic claims and promoting forms of civil exclusion rather than incorporation.

These qualifications stem from the weaker, non-substantive definition of populism that this paper has proposed: if populism is taken to be a formal mode of doing politics, rather than a substantive set of political ideas, whether it promotes civil restriction or repair, or both, is not something that can be settled in the abstract. The main purpose of this paper has been to suggest that many of populism's formal dynamics can be connected, via CST, to what is usually considered to be non-populist politics, and, via cultural sociology, to the routine ways in which culture operates in most other spheres of social life.

Just as routine processes of group identity formation structure their meaning around either/ or oppositions, so too does populism work the binaries of the civil sphere, cementing unity with those it defines as a "people", and breaking ties with those it does not. Understanding populism as a mode of public signification rather than an ideology (thin-centred or otherwise)

\footnotetext{
${ }^{13}$ For an illustration of the fundamental inadequacies of fact-based politics in shaping perceptions, feelings, and motivations, see Smith and Howe's (2015) analysis of climate consciousness.
} 
allows us to recognize it as a form of cultural work that codes its own motivations, relationships, and institutions in civil terms, and those of its adversaries in terms of the opposite. Just as in other spheres of cultural distinction, moral judgements of good and evil animate these classifications, so that populism's efficacy is determined as much, and often more so, by its persuasive power in appealing to an audience's values and feelings, as by its ability to rationally demonstrate its propositions. Finally, this paper has defended against the view that populism is inherently anti-pluralist, suggesting that populist signification can, and often does, operate within a broader acknowledgement of civil togetherness.

Since politics - and populism as a specific mode of doing politics - is obligated to operate through culture (which is of course different to the reductive claim of saying it simply is culture), effective social scientific tools for analyzing culture are, unsurprisingly, also effective tools for analyzing populism. Moreover, populism paints boldly what more routine politics tends to sketch more faintly: its categorizations are clear-cut, its public significations sharp, its binaries transparent, and its moral and emotional resonances distinct. Within it, we can discern clearly the structured ways in which culture reduces complexity, allowing information to be conveyed and meaning organized. Focusing our attention on such pronounced modes of political expression promises therefore to strengthen our understanding of the civil sphere.

Acknowledgements This paper was originally presented at the Civil Sphere and Populism Conference in June 2019 at Yale University. This event was sponsored by the Edward J. \& Dorothy Clarke Kempf Memorial Fund, the Yale Macmillan Centre for International and Area Studies, the International Migration Laboratory of University of Trento, and the Center for Cultural Sociology at Yale University. Thank you especially to the organisers of that conference-Jeffrey Alexander, Peter Kivisto, and Giuseppe Sciortino-for their advice in revising the paper. Thank you also for the generous feedback from all the conference participants, and the anonymous IJPCS reviewers.

\section{Compliance and Ethical Standards}

Conflict of Interest The author declares that he has no conflicts of interest. This research did not involve human participants and/or animals. Informed consent was therefore unnecessary.

Open Access This article is licensed under a Creative Commons Attribution 4.0 International License, which permits use, sharing, adaptation, distribution and reproduction in any medium or format, as long as you give appropriate credit to the original author(s) and the source, provide a link to the Creative Commons licence, and indicate if changes were made. The images or other third party material in this article are included in the article's Creative Commons licence, unless indicated otherwise in a credit line to the material. If material is not included in the article's Creative Commons licence and your intended use is not permitted by statutory regulation or exceeds the permitted use, you will need to obtain permission directly from the copyright holder. To view a copy of this licence, visit http://creativecommons.org/licenses/by/4.0/.

\section{References}

Albertazzi, D., \& McDonnel, D. (Eds.). (2007). Twenty-first century populism: the spectre of Western European Democracy. Basingstoke: Palgrave Macmillan.

Alexander, J. C. (2006). The civil sphere. Oxford: Oxford University Press.

Alexander, J. C. (2010). The performance of politics: Obama's victory and the democratic struggle for power. Oxford: Oxford University Press.

Alexander, J. C. (2011). Performative revolution in Egypt: an essay in cultural power. In London. New York: Bloomsbury Academic. 
Alexander, J. C. (2013). 'De-civilizing the civil sphere', The dark side of modernity (pp. 123-139). Cambridge: Polity Press.

Alexander, J. C. (2015). Nine theses on the civil sphere. In P. Kivisto \& G. Sciortino (Eds.), Solidarity, justice, and incorporation: thinking through the civil sphere. Oxford: Oxford University Press.

Alexander, J. C. (2019). Frontlash/Backlash: the crisis of solidarity and the threat to civil institutions. Contemporary Sociology: A Journal of Reviews, 48(1), 5-11.

Alexander, J. C., \& Smith, P. (1993). The discourse of American civil society: a new proposal for cultural studies. Theory and Society, 22(2), 151-207.

Arnold, M. [1863] (1993). Culture \& anarchy and other writings, ed. Stefan Collini, Cambridge: Cambridge University Press.

Aslanidis, P. (2016). Is populism an ideology? A refutation and a new perspective. Political Studies, 64, 88-104.

Aslanidis, P. (2018). Populism as a collective action master frame for transnational mobilization. Sociological Forum, 33(2), 443-464.

Badiou, A., Bourdieu, P., Butler, J., Didi-Huberman, G., Khiari, S., \& Rancière, J. (2016). What is a people? New York: Columbia University Press.

Barthes, R. (1977). Introduction to the structural analysis of narratives. In Image Music Text (pp. 79-124). Fontana Press.

Berlin, I., Hofstadter, R., MacRae, D., Schapiro, L., Seton-Watson, H., Touraine, A., Venturi, F., Walicki, A., \& Worsley, P. (1968). To define populism. Government and Opposition, 3(2), 137-179.

Bickerton, C. (2018). The collapse of Europe's mainstream centre left. New Statesman, 1st May, 2018.

Blair, T. (1999), Full speech to labour conference, The Guardian, Tuesday, 28th September.

Bonikowski, B. (2016). Three lessons of contemporary populism in Europe and the United States. Brown Journal of World Affairs, 23, 9.

Bonikowski, B., N. Gidron, (2016) Multiple Traditions in Populism Research: Toward a Theoretical Synthesis. APSA Comparative Politics Newsletter, 26(12), 7-14.

Bourdieu, P. (1984). Distinction: a social critique of the judgement of taste. Cambridge: Harvard University Press.

Brubaker, R. (2017). Why populism? Theory \& Society, 46, 357-385.

Canovan, M. (1999). Trust the people! Populism and the two faces of democracy. Political Studies, 47(1), 2-16.

Crick, B. (1962). In defence of politics. London: Bloomsbury.

Crouch, C. (2000). Coping with post-democracy. London: Fabian Society.

Crouch, C. (2004). Post-democracy. Cambridge: Polity Press.

Davies, W. (2019). Nervous states: how feeling took over the world. London: Jonathan Cape.

de Saussure, F. (1893)/1915. Course in general linguistics, ed. Bally, C. \& Riedlinger, A., London: McGrawHill.

Derrida, J. (1981). Positions, trans., Alan Bass, Chicago: Chicago: University of Chicago Press.

Douglas, M. (1983). Morality and culture. Ethics, 93(4), 786-791.

Durkheim, É. (1973). In R. N. Bellah (Ed.), On morality and society. Chicago: University of Chicago Press.

Durkheim, É. [1893] (1984). The division of labour in society, London: Palgrave Macmillan.

Durkheim, É. [1912] (1995). The elementary forms of the religious life. London: The Free Press.

Durkheim, É. \& Mauss, M. [1903] (2009). Primitive classification, Introduced by Rodney Needham. London: Routledge.

Eatwell, R., \& Goodwin, M. (2018). National populism: the revolt against liberal democracy. London: Penguin.

Ekström, M., Patrona, M., \& Thornborrow, J. (2018). Right-wing populism and the dynamics of style: a discourse-analytic perspective on mediated political performances. Palgrave Communications, 4(1), 83.

Elster, J. (1998). Alchemies of the mind. Cambridge: Cambridge University Press.

Firth, R. (1958). Reason and unreason in human belief. In Human Types. London, Thomas Nelson.

Foucault, M. (1988). Madness and civilization: a history of insanity in an age of reason. London: Vintage Books.

Foucault, M. (2007). Security, territory, population: lectures at the Collège de France 1977-1978. London: Palgrave Macmillan.

Fukuyama, F. (2016). American political decay or renewal? Foreign Affairs, (July/August 2016).

Galston, W. A. (2018). Anti-pluralism: the populist threat to liberal democracy. Yale University Press.

Geertz, C. (1957). Ethos, world-view and the analysis of sacred symbols. The Antioch Review, 17(4), 421-437.

Geertz, C. (1968). Thinking as a moral act: ethical dimensions of anthropological fieldwork in the new states. The Antioch Review, 28(2), 139-158.

Geertz, C. (1973). The interpretation of cultures. New York: Basic Books.

Giddens, A. (1994). Beyond left \& right. Cambridge: Polity Press.

Goodhart, D. (2017). The road to somewhere: the populist revolt and the future of politics. Oxford University Press. 
Goodwin, J., Jasper, J. M., \& Polletta, F. (Eds.). (2001). Passionate politics. Chicago: University of Chicago Press.

Gorski, P. (2017). Why evangelicals voted for Trump: a critical cultural sociology. American Journal of Cultural Sociology, 5(3), 338-354.

Gramsci, A. (1971). Selections from the prison notebooks. London: Lawrence \& Wishart.

Habermas, J. (1976). Legitimation crisis. London: Heinemann Educational.

Hall, S. (1979). The great moving right show. Marxism Today, January.

Hall, S. (1998). The great moving nowhere show. Marxism Today, November/December.

Herdin, T. (2012). Deconstructing typologies: overcoming the limitations of the binary opposition paradigm. The International Communication Gazette, 74(7), 603-618.

Ionescu, G., \& Gellner, E. (1969). Populism: its meanings and national characteristics. Letchworth: Garden City Press.

Jäger, A. (2018). The myth of "populism”. Jacobin, 3rd January.

James, W. 1981 [1907]. Pragmatism. Cambridge: Hackett Publishing Company.

Jansen, R. S. (2011). Populist mobilization: a new theoretical approach to populism. Sociological Theory, 29(2), 75-96.

Judis, J. B. (2016). The populist explosion: how the great recession transformed American and European politics. New York: Columbia Global Reports.

Kivisto, P. (2017). The Trump phenomenon: how the politics of populism won in 2016. Bingley: Emerald.

Kreisi, H. (2014) The Populist Challenge, West European Politics, 37(2), 361-378.

Laclau, E. (1996). 'Why do empty signifiers matter to politics?', Emancipation(s) (pp. 36-46). London: Verso.

Laclau, E. (2005). On populist reason. London: Verso.

Laclau, E. (2006). Why constructing a people is the main task of radical politics. Critical Inquiry, 32(4), 646680 .

Lamont, M., \& Molnár, V. (2002). The Study of Boundaries in the Social Sciences. Annual Review of Sociology, 28(1):167-195.

Le Bon, G. [1896] (2006), The crowd: a study of the popular mind. New York: Cosimo.

Levi-Strauss, C. (1967). Structural anthropology. Anchor Books.

Loseke, D. (1993). Constructing conditions, people, morality, and emotion: expanding the agenda of constructionism. New York: Routledge.

Lynch, G. (2012). The sacred in the modern world: a cultural sociological approach. Oxford: Oxford University Press.

MacRae, D. (1969), 'Populism as an Ideology', Ionescu, G. \& Gellner, E. Populism: its meanings and national characteristics, Letchworth: Garden City Press, pp. 153-166.

Mair, P. (2013). Ruling the void: the hollowing-out of Western democracy. London: Verso.

Marcus, G. (2000). Emotions in politics. Annual Review of Political Science, 3(1), 221-250.

Mast, J. L. (2012). The performative presidency: crisis and resurrection during the Clinton years. Cambridge: Cambridge University Press.

Moffitt, B. (2016). The global rise of populism: performance, political style, and representation. Stanford: Stanford University Press.

Morgan, M. (2014). The poverty of (moral) philosophy: towards an empirical and pragmatic ethics. European Journal of Social Theory, 17(2), 129-46.

Morgan, M. (2016). Humanising sociological knowledge. Social Epistemology, 30(5-6), 555-71.

Morgan, M. (2018). Performance and power in social movements: Biko's role as a witness in the SASO/BPC Trial. Cultural Sociology, 12(4), 457-77.

Morgan, M. (2020). Movement intellectuals engaging the grassroots: a strategy perspective on the black consciousness movement. The Sociological Review. https://doi.org/10.1177/0038026119900118.

Mouffe, C. (1993). Introduction: Schmitt's challenge. In C. Mouffe (Ed.), The return of the political. London: Verso.

Mouffe, C. (Ed.). (1999). The challenge of Carl Schmitt. London: Verso.

Mouffe, C. (2002). Politics and passions: the stakes of democracy. London: Centre for the Study of Democracy.

Mouffe, C. (2013). Agonistics: thinking the world politically. London: Verso.

Mouffe, C. (2018). For a left populism. London: Verso Books.

Mouffe, C., \& Errejón, I. (2016). Podemos: in the name of the people. London: Lawrence \& Wishart Ltd..

Mounk, Y. (2018). The people vs. democracy. Cambridge: Harvard University Press.

Mudde, C. (2004). The populist zeitgeist. Government and Opposition, 39(4), 541-563.

Mudde, C., \& Kaltwasser, C. R. (2017). Populism: a very short introduction. Oxford: Oxford University Press.

Müller, J. W. (2016). What is populism? Philadelphia: University of Pennsylvania Press.

Obama, B., (2016). I'm the real populist, not Trump', Politico. https://www.politico.com/video/2016/06/obamaim-the-real-populist-not-trump-059801. Accessed 29 May 2020. 
Peel, P. (2018). The populist theory of the state in early American political thought. Political Research Quarterly., 71(1), 115-126.

Rancière, J. (1998). Disagreement. Minneapolis: University of Minnesota Press.

Rancière, J. (2003). Comment and responses. Theory \& Event, 6(4).

Rico, G., Guinjoan, M., \& Anduiza, E. (2017). The emotional underpinnings of populism: how anger and fear affect populist attitudes. Swiss Political Science Review, 23(4), 444-461.

Rorty, R. (1982). Consequences of pragmatism. Minneapolis: University of Minnesota Press.

Ruzza, C., \& Fella, S. (2009). Re-inventing the Italian right. Territorial Politics, Populism and "Post-Fascism". New York: Routledge.

Sandel, M. J. (2018). Populism, liberalism, and democracy. Philosophy \& Social Criticism, 44(4), 353-359.

Schmidt, V. A. (2006). Democracy in Europe: the EU and National Polities. Oxford: Oxford University Press.

Schmitt, C. [1932] (2007), The concept of the political. Chicago: Chicago University Press.

Serge, V. [1951] (2012) Memoirs of a revolutionary. New York: New York Review of Books Classics.

Skinner, Q. (2009). A genealogy of the modern state'. Proceedings of the British Academy., 162, 352-370.

Smith, P., \& Howe, N. (2015). Climate change as social drama: global warming in the public sphere. Cambridge: Cambridge University Press.

Stanley, B. (2008). The thin ideology of populism. Journal of Political Ideologies, 13(1), 95-110.

Stavrakakis, Y., A. Jäger (2018). Accomplishments and limitations of the 'new' mainstream in contemporary populism studies. European Journal of Social Theory, 21(4), 547-565

Stewart, H., \& Elgot, J. (2016). Labour plans Jeremy Corbyn relaunch to ride anti-establishment wave. The Guardian.

Taguieff, P. A. (1995). Political science confronts populism: from conceptual mirage to a real problem. Telos., $103,9-43$.

Toynbee, P. (2015). This was the week the Labour leadership contest turned nasty, The Guardian, 23rd July.

Turner, B. S. (2015). Civil sphere and political performance: critical reflections on Alexander's cultural sociology. In P. Kivisto \& G. Sciortino (Eds.), Solidarity, justice \& incorporation: thinking through the civil sphere. Oxford: Oxford University Press.

Urbinati, N. (2017). Populism and the principle of majority. In C. R. Kaltwasser, P. Taggart, P. O. Espejo, \& P. Ostiguy (Eds.), The Oxford handbook of populism. Oxford: Oxford university Press.

Wagner-Pacifici, R., \& Tavory, I. (2017). Politics as a vacation. American Journal of Cultural Sociology, 5(3), $307-321$.

Weber, C. (2012). Emotions, campaigns, and political participation. Political Research Quarterly, 66(2), 414 428.

Wolf, M. (2017). The economic consequences of Jeremy Corbyn. Financial Times, 5th October.

Woodly, D. R. (2015). The politics of common sense: how social movements use public discourse to change politics and win acceptance. Oxford: Oxford University Press.

Publisher's Note Springer Nature remains neutral with regard to jurisdictional claims in published maps and institutional affiliations. 